\title{
Phycobiliproteins Ameliorate Gonadal Toxicity in Male Mice Treated with Cyclophosphamide
}

\author{
Jorge Briseño-Bugarín ${ }^{1}$, Isabel Hernández-Ochoa ${ }^{2}$, Xelha Araujo-Padilla ${ }^{1} \mathbb{D}$, María Angélica Mojica-Villegas ${ }^{1}{ }^{1}$, \\ Ricardo Iván Montaño-González ${ }^{1}\left(\mathbb{D}\right.$, Gabriela Gutiérrez-Salmeán ${ }^{3}(\mathbb{D})$ and Germán Chamorro-Cevallos ${ }^{1, *} * \mathbb{D}$ \\ 1 Departamento de Farmacia, Escuela Nacional de Ciencias Biológicas, Instituto Politécnico Nacional, \\ Unidad Zacatenco, Mexico City 07738, Mexico; jorbribu@gmail.com (J.B.-B.); \\ xelhaaraujo@gmail.com (X.A.-P.); angiemojica13@gmail.com (M.A.M.-V.); \\ bassinpi_314@hotmail.com (R.I.M.-G.) \\ 2 Departamento de Toxicología, Centro de Investigación y de Estudios Avanzados del Instituto Politécnico \\ Nacional (Cinvestav-IPN), Unidad Zacatenco, Mexico City 07360, Mexico; mihernandez@cinvestav.mx \\ 3 Centro de Investigación en Ciencias de la Salud (CICSA), Facultad de Ciencias de la Salud, \\ Universidad Anáhuac México, Mexico City 52786, Mexico; gabrielasalmean@yahoo.com \\ * Correspondence: gchamcev@yahoo.com.mx
}

check for updates

Citation: Briseño-Bugarín, J.; Hernández-Ochoa, I.; Araujo-Padilla, X.; Mojica-Villegas, M.A.; Montaño-González, R.I.; Gutiérrez-Salmeán, G.; Chamorro-Cevallos, G. Phycobiliproteins Ameliorate Gonadal Toxicity in Male Mice Treated with Cyclophosphamide. Nutrients 2021, 13, 2616. https://doi.org/10.3390/ nu13082616

Academic Editor: Arrigo Cicero

Received: 14 May 2021

Accepted: 26 July 2021

Published: 29 July 2021

Publisher's Note: MDPI stays neutral with regard to jurisdictional claims in published maps and institutional affiliations.

Copyright: (c) 2021 by the authors. Licensee MDPI, Basel, Switzerland. This article is an open access article distributed under the terms and conditions of the Creative Commons Attribution (CC BY) license (https:/ / creativecommons.org/licenses/by/ $4.0 /)$.
Abstract: Cyclophosphamide (CP) —which is used to treat autoimmune diseases and cancer-is related to gonadotoxicity attributed to oxidative stress. As phycobiliproteins (PBPs) are strong antioxidants that are unexplored as protective agents against male gonadotoxicity, our work aimed to investigate the effects of PBP crude extract on testicular damage and sperm parameter alterations caused by CP in mice. Three doses of PBP $(50,100$, and $200 \mathrm{mg} / \mathrm{kg})$ were tested in the experimental groups ( $n=8$ per group), administered concomitantly with $100 \mathrm{mg} / \mathrm{kg}$ CP. After 42 days receiving PBP daily and CP weekly, body and relative testicular weights, serum testosterone levels, testicular lipoperoxidation and antioxidant enzyme activity levels, and testicular histology and sperm parameter alterations were assessed. The results showed that PBP crude extract at $200 \mathrm{mg} / \mathrm{kg}$ prevented testosterone serum reduction, body weight loss, lipoperoxidation and enzyme activity increments, and sperm parameter alterations and partially ameliorated relative testicular weight reductions and histological damage in CP-treated mice. In conclusion, we showed that PBP crude extract $(200 \mathrm{mg} / \mathrm{kg})$ mitigated oxidative damage in the testes and ameliorated alterations in sperm parameters in mice treated with CP $(100 \mathrm{mg} / \mathrm{kg})$; therefore, PBP extract could be considered as a potential protective agent against $\mathrm{CP}$ toxicity.

Keywords: phycobiliproteins; cyclophosphamide; testicular damage; sperm parameters

\section{Introduction}

Cyclophosphamide (CP) is a prodrug with alkylating activity that is widely used in chemotherapy, autoimmune disorders, and organ transplantation [1]. Despite its pharmacological benefits, CP has been associated with gonadotoxicity [2-4]. CP deteriorates sperm quality and atrophies testicular tissue in both humans and mice [5,6]. It also reduces superoxide dismutase (SOD) and glutathione peroxidase (GPX) activities in rat testes [7] and causes reductions correlated with impaired sperm quality in infertile patients [8,9]. CP metabolism generates active molecules such as phosphoramide mustard and acrolein [10], which are associated with therapeutic effect and toxicity, respectively [11]. Acrolein-a strong electrophile-creates oxidative stress conditions, modifies antioxidant enzymes [3], and reduces fertility in CP-treated patients [12]. As sperm cryopreservationwhich is inaccessible to the majority of the population-is recommended before receiving chemotherapy $[13,14]$, supplementation with phytocompounds and natural antioxidants has been proposed because they restore antioxidant balance and enhance male fertility [15]. C-phycocyanin (C-PC), allophycocyanin (APC), and phycoerythrin (PE) - known as phycobiliproteins (PBPs) [16] - are water-soluble fluorescent pigments found in cryptomonads, 
cyanelles, and cyanobacteria such as Spirulina maxima (SP) [17]. PBP extracts demonstrate antioxidant, antimicrobial, antiviral, antitumor, anti-inflammatory [18], antiteratogenic [19], antiulcerogenic [20], and nephroprotective [21] effects as well as preeclampsia-preventive activity [22]. Considering that PBPs' activity against drug-induced gonadotoxicity is unexplored, the present work aimed to probe whether PBP extracted from SP could ameliorate testicular damage caused by multiple doses of $\mathrm{CP}$ in mice.

\section{Materials and Methods}

\subsection{Reagents and Spirulina}

Spirulina maxima powder was donated by Alimentos Esenciales para la Humanidad S.A. de C.V. (Mexico City, Mexico). Reagents and CP (CAS 6055-19-2, purity $\geq 98 \%$ ) were purchased from Sigma-Aldrich Chemicals Co. (St. Louis, MO, USA) except for RANSOD and RANSEL kits obtained from Randox Laboratories (Crumlin, UK) and a testosterone enzyme-linked immunosorbent assay (ELISA) kit purchased from Cayman Chemical Co. (Ellsworth, MI, USA). All reagents were analytical grade.

\subsection{PBP Extraction and Determination}

Phycobiliproteins were extracted as described by Maurya et al. [23] by diluting SP (5 g) in phosphate-buffered saline $(20 \mathrm{~mL}, 20 \mathrm{mM}, \mathrm{pH} 7.2)$. SP solution $(0.25 \mathrm{~g} / \mathrm{mL})$ was frozen $\left(-70{ }^{\circ} \mathrm{C}\right)$, thawed $\left(24 \pm 2{ }^{\circ} \mathrm{C}\right)$, shaken $\left(5 \mathrm{~min}, 24 \pm 2{ }^{\circ} \mathrm{C}\right)$ in darkness, and centrifuged twice at 14,000 rpm (JA-17 rotor, Beckman Coulte Co., Indianapolis, IN, USA) for $30 \mathrm{~min}$ at $4{ }^{\circ} \mathrm{C}$. The supernatant was collected, PBPs were identified, and then the remaining supernatant was lyophilized and stored at $-70{ }^{\circ} \mathrm{C}$ in darkness conditions. C-PC, APC, and PE optical densities (O.D.) were, respectively, determined at 615, 652, and $562 \mathrm{~nm}$, while PBP concentrations were estimated as described by Bennett and Bogorad [24] and described using the following formulas:

$$
\begin{gathered}
\text { C-PC }(\mathrm{mg} / \mathrm{mL})=[\text { O.D. } 615-0.474(\text { O.D.652) })] / 5.34 \\
\text { APC }(\mathrm{mg} / \mathrm{mL})=[\text { O.D. } 652-0.208(\text { O.D. } 615)] / 5.09, \\
\operatorname{PE~}(\mathrm{mg} / \mathrm{mL})=[\text { O.D. } .562-2.41(\text { C-PC }(\mathrm{mg} / \mathrm{mL}))-0.849(\text { APC }(\mathrm{mg} / \mathrm{mL}))] / 9.62 .
\end{gathered}
$$

C-PC, APC, and PE purity indexes were estimated by dividing each O.D. by the total protein O.D. determined at $280 \mathrm{~nm}$, while extraction yields were calculated from the wet basis by the following formula:

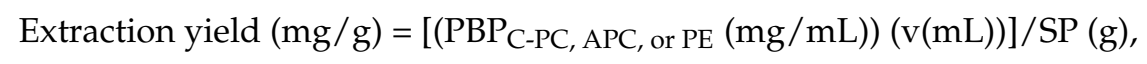

where PBPC-PC, APC, and PE $(\mathrm{mg} / \mathrm{mL})$ represent the C-PC, APC, or PE concentration obtained, while $\mathrm{v}$ indicates the volume of phosphate-buffered saline.

\subsection{Animals}

The CD-1 male mice (25-30 g, 6-7 weeks old) from Bioterium of Universidad Autónoma del Estado de Hidalgo (Pachuca de Soto, Mexico) were housed in cages with access to LabDiet Rodent 5001 food (Fort Worth, TX, USA) and water ad libitum at constant temperature $\left(24 \pm 2{ }^{\circ} \mathrm{C}\right)$ and relative humidity $(50 \pm 10 \%)$ and with $12 \mathrm{~h}$ light/dark cycles. Conditions were maintained after and during the experimental procedures. The investigation protocol was previously approved by the Bioethical Committee of the National School of Biological Sciences of the National Polytechnic Institute (protocol code: ZOO-016-2020; 21 December 2020 ), and procedures with animals were performed in accordance with Mexican Official Standard NOM-062-ZOO-2001.

\subsection{Experimental Design}

Cyclophosphamide was dissolved in physiological solution $(0.9 \% \mathrm{NaCl})$ and administered intraperitoneally at $100 \mathrm{mg} / \mathrm{kg}$ as described by Elangovan et al. [25], and Lu et al. [7], 
while PBPs were dissolved in phosphate-buffered saline and administered intragastrically at 50, 100, and $200 \mathrm{mg} / \mathrm{kg}$ - doubling and halving the $100 \mathrm{mg} / \mathrm{kg}$ dose reported by Castro-García et al. [22]. After an acclimatization week, treated male mice received daily i.g. doses of 50, 100, or $200 \mathrm{mg} / \mathrm{kg}$ PBP for 42 days concomitantly with weekly i.p. doses of $100 \mathrm{mg} / \mathrm{kg} \mathrm{CP}$ (Figure 1). Control groups were included; whereby the vehicle control group received i.g. $0.9 \% \mathrm{NaCl}$ daily for 42 days, the $\mathrm{CP}$ group received weekly i.g. doses of $100 \mathrm{mg} / \mathrm{kg}$ for 5 weeks, and the PBP group received daily i.p. doses of $200 \mathrm{mg} / \mathrm{kg}$ for 42 days; thus, experimental groups were defined as control, $\mathrm{CP}, \mathrm{PBP}, \mathrm{PBP} 50+\mathrm{CP}$, PBP100 + CP, and PBP200 + CP. At the end of treatment (day 42), the procedures described in Sections 2.5-2.9 were performed.

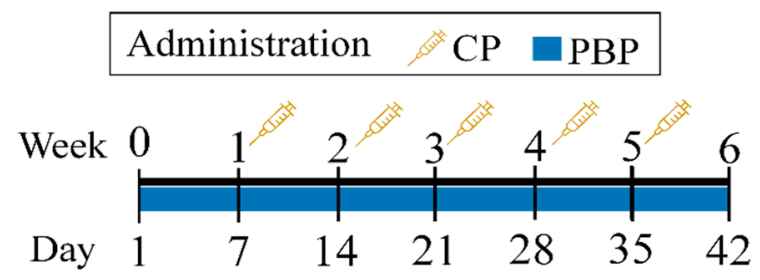

Figure 1. Cyclophosphamide (CP) and phycobiliprotein (PBP) extract administration. Treated male mice received daily i.g. doses of 50, 100, or $200 \mathrm{mg} / \mathrm{kg}$ PBP for 42 days concomitantly with weekly i.p. doses of $100 \mathrm{mg} / \mathrm{kg} \mathrm{CP}$.

\subsection{Serum Testosterone, Body Weight, and Relative Testicular Weight}

Blood was collected by retro-orbital bleeding on day 42 , and serum samples were separated to quantify testosterone levels using an ELISA kit. Mice were weighed and euthanized by cervical dislocation to immediately dissect the testes and epididymis and to determine the relative testicular weight.

\subsection{Lipoperoxidation and SOD and GPX Activity in the Testes}

The left testicle was homogenized in physiological solution by sonication for $40 \mathrm{~s}$ (output 40\%, 20 kHz; Ultrasonic Homogenizer VP-050N, Taitec Corp., Koshigaya City, Saitama, Japan). Testicle homogenates were centrifuged at 10,000 rpm (1619 Rotor Universal 320 Centrifuge, Hettich ${ }^{\circledR}$, Tuttlingen, DE) for $10 \mathrm{~min}$ at $4{ }^{\circ} \mathrm{C}$ and the supernatants were collected to evaluate lipoperoxidation and the enzymatic activity levels of SOD and GPX. Before determination, the total protein concentrations in supernatants were calculated by Bradford assay. Lipoperoxidation was determined by malondialdehyde (MDA) identification using thiobarbituric acid as proposed by Buege and Aust [26]. SOD and GPX activity levels were evaluated using RANSOD and RANSEL kits, respectively, following the manufacturers ${ }^{\prime}$ instructions.

\subsection{Testicular Histology}

The right testicle was conserved in buffered formaldehyde $(4 \%$, $\mathrm{pH} 7.4)$ until histologic observation and histomorphometry. After being dehydrated and embedded in paraffin [27], testicle sections of $5 \mu \mathrm{m}$ thickness were prepared for hematoxylin and eosin (H\&E) staining [28]. Ten stained sections per testicle were analyzed using an Olympus BX61 microscope (Olympus Corp., Shinjuku, Tokyo, Japan).

\subsection{Histomorphometry}

Morphology changes in seminiferous tubules were determined in five different fields from each testicle section. The total seminiferous tubule area (TSTA) and lumen tubule area (LTA) were measured with Image-Pro Plus ${ }^{\circledR}$ software (Media Cybernetics Inc., Rockville, MD, USA). Next, the seminiferous tubule area (STA) was estimated as the difference between the TSTA and LTA (Figure 2). 


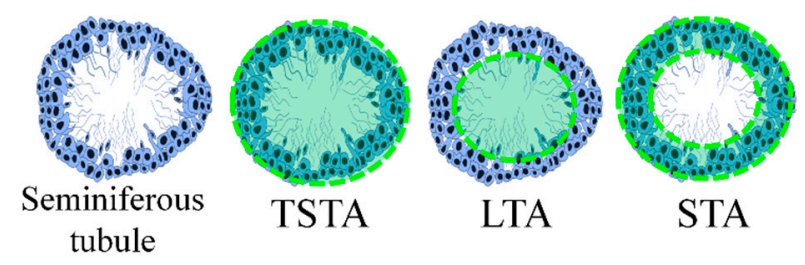

Figure 2. Schematic representation of the seminiferous tubule area. The total seminiferous tubule area (TSTA), lumen tubule area (LTA), and seminiferous tubule area (STA) were measured as the marked green areas indicate.

\subsection{Sperm Parameter Assessment}

Epididymis spermatozoa were collected via flushing with M-16 medium (100 mM $\mathrm{NaCl}, 25 \mathrm{mM} \mathrm{NaHCO} 3,5.5 \mathrm{mM}$ glucose, $2.6 \mathrm{mM} \mathrm{KCl}, 1.56 \mathrm{mM} \mathrm{Na}_{2} \mathrm{HPO}_{4}, 0.5 \mathrm{mM}$ sodium pyruvate, $1.8 \mathrm{mM} \mathrm{CaCl}_{2}, 0.5 \mathrm{mM}, \mathrm{MgCl}_{2}, 20 \mathrm{mM}$ sodium lactate, $100 \mathrm{IU} / \mathrm{mg}$ penicillin, and $100 \mu \mathrm{g} / \mathrm{mL}$ streptomycin at $\mathrm{pH} 7.2$ and $37^{\circ} \mathrm{C}$ ). The progressive motility, sperm count, and cell viability were evaluated as sperm parameters according to World Health Organization guidelines [29]. Progressive motility was determined on a glass slide, sperm were counted in a hemocytometer, and sperm viability was evaluated by eosin-nigrosin exclusion assay; a phase contrast microscope (Carl Zeiss Microscopy Co., Oberkochen, Germany) was used for all determinations.

\subsection{Statistical Analysis}

The results were analyzed by one-way ANOVA followed by the Holm-Sidak multiple comparison test. Data were represented as means \pm standard error of the mean (SEM), and $p<0.05$ was considered statistically significant. The PBP, PBP50 $+\mathrm{CP}, \mathrm{PBP} 100+\mathrm{CP}$, and PBP200 + CP groups were compared with the control and CP groups. Analysis was performed and graphs were produced in SigmaPlot v12.0 software. All samples were evaluated in triplicate.

\section{Results}

\subsection{PBP Determination}

The PBP concentrations, purity index values, and extraction yields are indicated in Table 1. C-PC, APC, and PE, respectively, corresponded to $69.04,30.34$, and $0.62 \%$ of the PBPs extracted from SP, with C-PC being 2.3- and 111.5-fold more abundant than APC and $\mathrm{PE}$, respectively. Additionally, the purity index and extraction yield of C-PC were higher than the purity index values and extraction yields of APC and PE.

Table 1. PBP concentrations, purity index values, and extraction yields.

\begin{tabular}{cccc}
\hline PBP & $\begin{array}{c}\text { Concentration } \\
(\mathbf{m g} / \mathbf{m L})\end{array}$ & Purity Index & $\begin{array}{c}\text { Extraction Yield } \\
\mathbf{( m g / g , ~ w b ~ S P ) ~}\end{array}$ \\
\hline C-PC & $2.23 \pm 0.02$ & $0.7 \pm 0.02$ & $8.93 \pm 0.44$ \\
APC & $0.98 \pm 0.14$ & $0.3 \pm 0.02$ & $3.91 \pm 0.56$ \\
PE & $0.02 \pm 0.001$ & $0.005 \pm 0.001$ & $0.08 \pm 0.004$ \\
\hline
\end{tabular}

Mean \pm standard deviation (SD) from triplicates; C-PC: phycocyanin; APC: allophycocyanin; PE: phycoerythrin; PBPs: phycobiliproteins; SP: Spirulina maxima; wb: wet basis.

\subsection{Serum Testosterone, Body Weight, and Relative Testicular Weight}

Figure 3 shows the results obtained from the testosterone serum determination. PBP at 100 and $200 \mathrm{mg} / \mathrm{kg}$ prevented the reductions in testosterone levels observed in the CP group. Although the PBP50 + CP group showed testosterone levels statistically lower than control, PBP50 + CP testosterone levels were $7.9 \%$ higher than the $\mathrm{CP}$ group. The body weight results (Figure 4a) showed that PBP at 50, 100, and $200 \mathrm{mg} / \mathrm{kg}$ prevented weight loss caused by $\mathrm{CP}$, while the relative testicular weight data (Figure $4 \mathrm{~b}$ ) indicated that all groups receiving $\mathrm{CP}$ decreased their relative testicular weight compared to control; 
however, the statistical analysis showed that the PBP200 + CP group presented relative testicular weights higher than those of the CP group, suggesting that the PBP $200 \mathrm{mg} / \mathrm{kg}$ dose ameliorated testicular weight reduction.

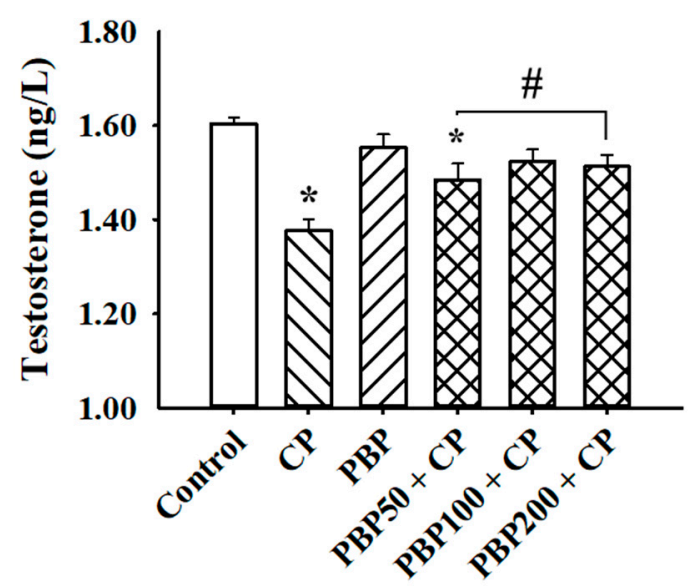

Figure 3. Effects of PBPs on testosterone levels of CP-treated mice. Testosterone levels evaluated in serum after treatment ended are represented as means \pm SEM. Results analyzed by one-way ANOVA followed by Holm-Sidak test. * Indicates $p<0.05$ vs. control group; \# indicates $p<0.05$ vs. CP group.
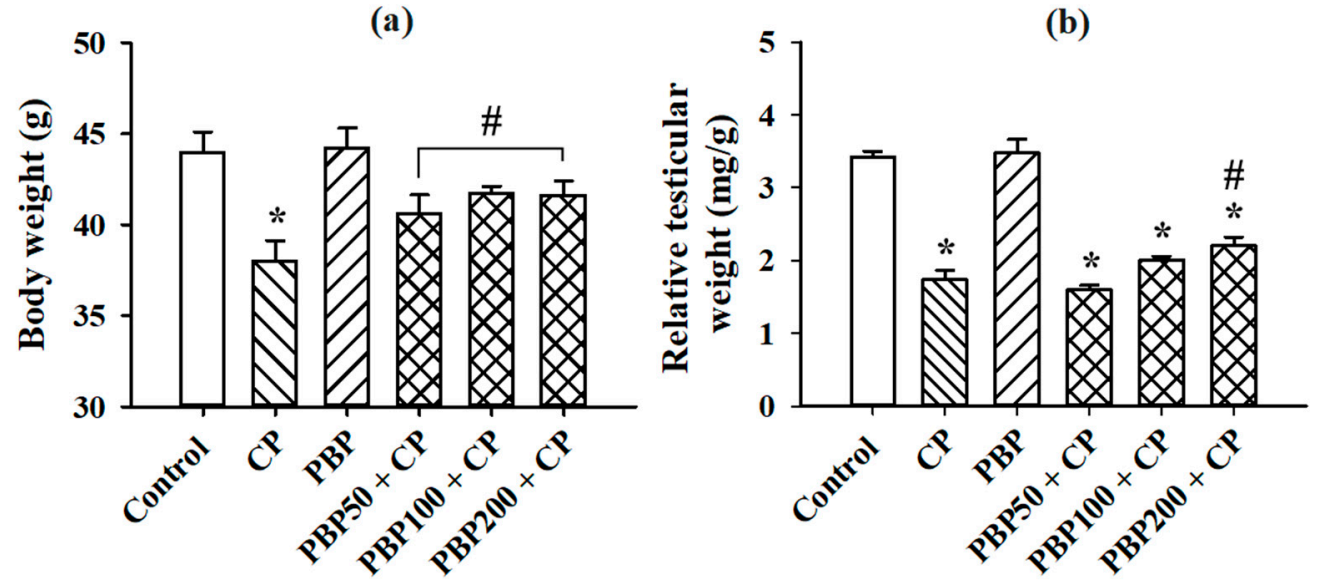

Figure 4. Effects of PBPs on body weight and relative testicular weight of CP-treated mice: (a) body weights measured at end of treatment, $(\mathbf{b})$ relative testicular weights. Means $\pm \mathrm{SEM}$ analyzed by one-way ANOVA followed by Holm-Sidak test. * Indicates $p<0.05$ vs. control group; \# indicates $p<0.05$ vs. CP group.

\subsection{Lipoperoxidation and SOD and GPX Activity in the Testes}

The MDA levels, determined as lipoperoxidation indicators, are shown in Figure 5. MDA in the CP group was fourfold greater than the control, while PBP50 + CP, PBP100 + CP, and PBP200 + CP groups maintained MDA at similar levels to the control group, suggesting a protective effect of PBP (50-200 mg/ $\mathrm{kg}$ ) against testicular lipoperoxidation induced by CP. On the other hand, as presented in Figure 6, the enzymatic activity of SOD and GPX increased in the CP and PBP50 + CP groups compared with the control, while the PBP100 + CP and PBP200 + CP groups showed similar SOD and GPX activity levels to the control group. 


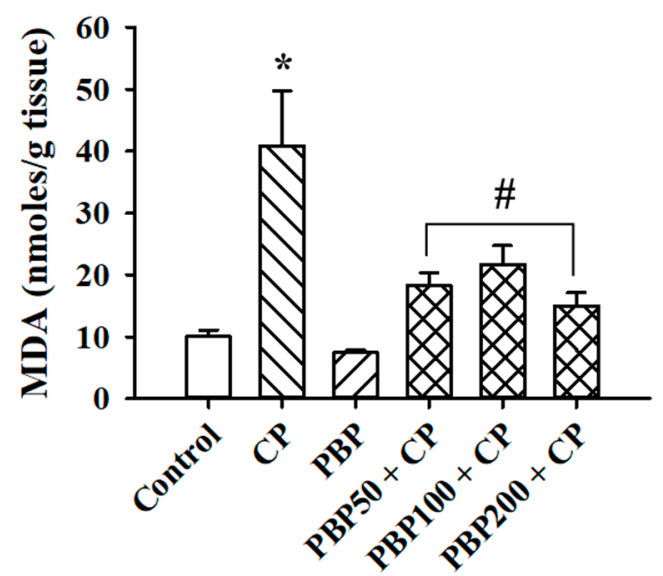

Figure 5. Effects of PBPs on testis lipoperoxidation of CP-treated mice. Malonaldehyde (MDA) was measured as an indicator of lipoperoxidation. Means \pm SEM analyzed by one-way ANOVA followed by Holm-Sidak test. * Indicates $p<0.05$ vs. control group; \# indicates $p<0.05$ vs. CP group.
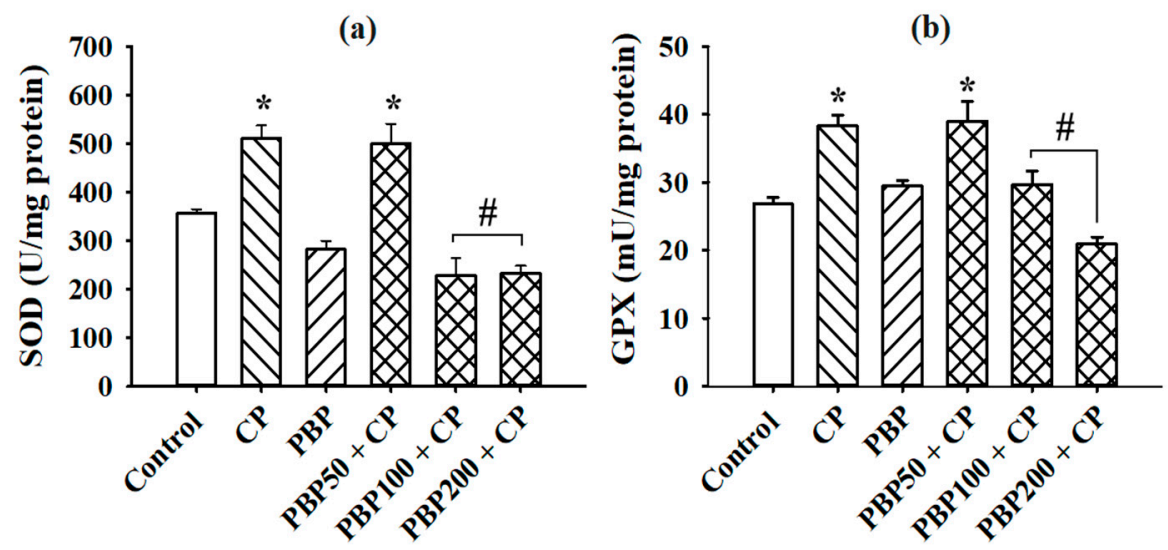

Figure 6. Effects of PBPs on SOD and GPX enzyme activities of CP-treated mice: (a) superoxide dismutase (SOD), (b) glutathione peroxidase (GPX). The activity levels were evaluated in mice testicles at the end of treatment. Means \pm SEM analyzed by one-way ANOVA followed by HolmSidak test. ${ }^{*}$ Indicates $p<0.05$ vs. control group; \# indicates $p<0.05$ vs. CP group.

\subsection{Testicular Histology}

Figure 7 shows representative micrographs from histological observations. The control and PBP groups presented intact seminiferous tubules where spermatogonium, spermatocytes, and spermatids were identified. Similarly, the PBP50 $+\mathrm{CP}, \mathrm{PBP} 100+\mathrm{CP}$, and PBP200 + CP groups preserved germinal cells from the basal membrane to the tubule lumen, while the CP group showed small tubules and large spaces in both the tubule lumen and interstitium, indicating possible depletion of cells, especially mature spermatids and Leydig cells. As interstitial spaces were also observed in PBP50 + CP micrographs, the testicular histology indicated that PBPs at the $50 \mathrm{mg} / \mathrm{kg}$ dose partially ameliorated damage caused by CP, while the 100 and $200 \mathrm{mg} / \mathrm{kg}$ doses improved testicle histology. 


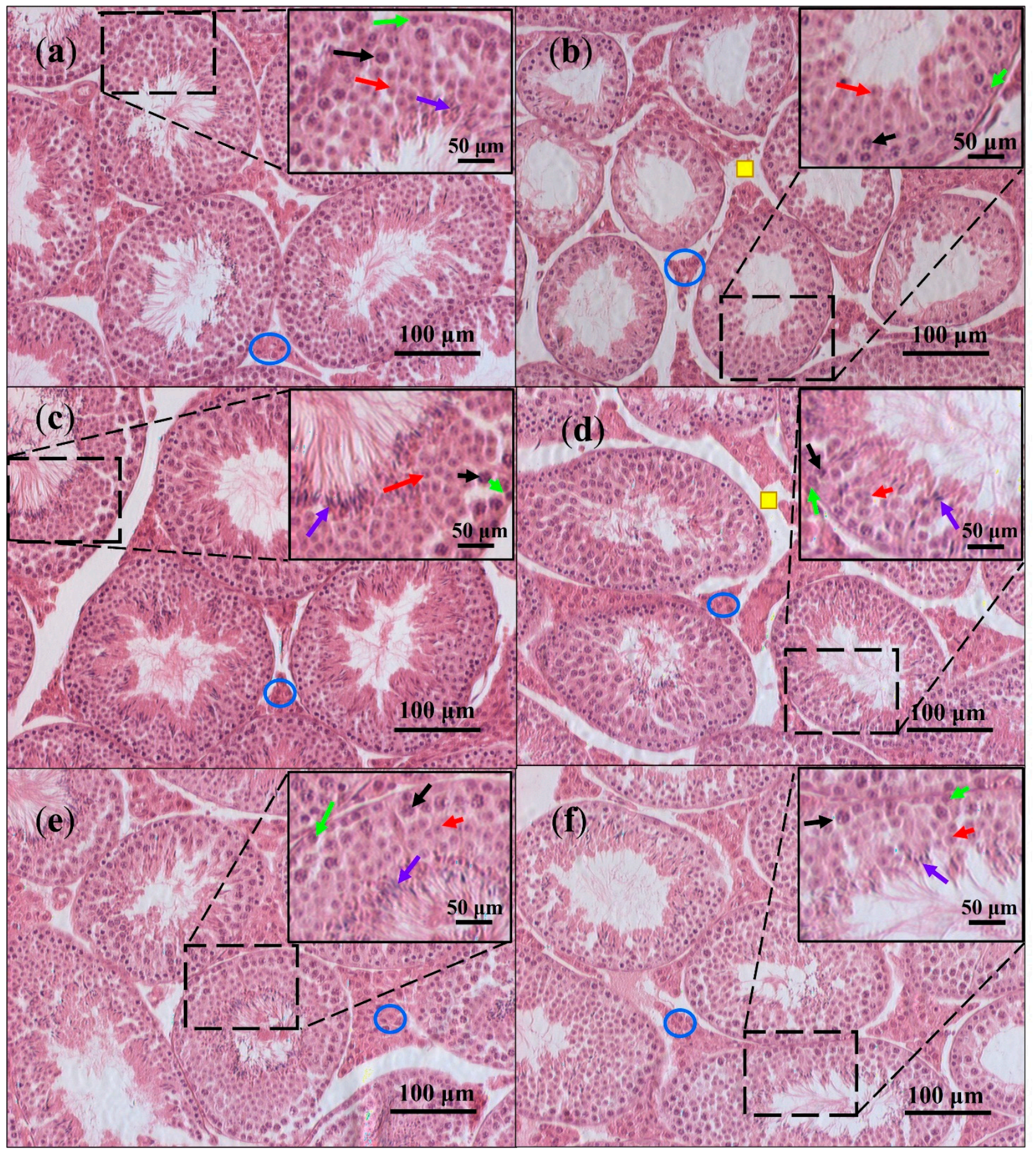

Figure 7. Effects of PBPs on the testicular histology of CP-treated mice: (a) The control group presented spermatogonium (green arrows), spermatocytes (black arrows), spermatids (red arrows), and mature spermatids (purple arrows) in seminiferous tubules and Leydig cells in interstitial space (blue circles); (b) the CP group showed small seminiferous tubules, large interstitial spaces (yellow squares), and several spermatids; (c) PBP, (d) PBP50 + CP, (e) PBP100 + CP, and (f) PBP200 + CP groups presented preserved germinal cells; however, large interstitial spaces were identified in PBP50 + CP (d). Boxes in the upper right corner are maximizations (X2) from specific field areas, as indicated by dashed lines. H\&E-stained sections observed at $10 \times$. 


\subsection{Histomorphometry}

The TSTA, LTA, and STA are shown in Table 2. Although large spaces in the seminal lumen were observed only in the $\mathrm{CP}$ group micrograph (Figure $\mathrm{7b}$ ), the LTA diminished in all the groups compared with the control, while TSTA was reduced only in the CP group. STA, which represented the seminal tubule cellular structure (Figure 2), was decreased in the $\mathrm{CP}$ group compared with the control, confirming tubule reduction in the $\mathrm{CP}$ micrograph (Figure 7b). The PBP50 + CP, PBP100 + CP, and PBP200 + CP groups presented STA values lower than the control but greater than the $\mathrm{CP}$ group, indicating partial improvement of testicular CP damage. Interestingly, TSTA and STA levels in the PBP group (without CP) were 12.8 and $21.9 \%$ higher than the control, respectively, suggesting that PBP consumption $(200 \mathrm{mg} / \mathrm{kg}$ ) contributed to germinal cell increase.

Table 2. Effects of PBP on seminiferous tubule areas of CP-treated mice. The total seminiferous tubule area (TSTA), lumen tubule area (LTA), and seminiferous tubule area (STA) were determined.

\begin{tabular}{cccc}
\hline Group & TSTA $\left(\boldsymbol{\mu \mathbf { m } ^ { \mathbf { 2 } } )}\right.$ & LTA $\left(\boldsymbol{\mu \mathbf { m } ^ { \mathbf { 2 } } )}\right.$ & STA $\left(\boldsymbol{\mu \mathbf { m } ^ { \mathbf { 2 } } )}\right.$ \\
\hline Control & $50,082 \pm 945.4$ & $10,771 \pm 342.4$ & $39,311 \pm 755.1$ \\
CP & $24,764 \pm 511.3^{\mathrm{a}}$ & $7763 \pm 251.0^{\mathrm{a}}$ & $17,001 \pm 396.9^{\mathrm{a}}$ \\
PBP & $56,481 \pm 1535^{\mathrm{ab}}$ & $8575 \pm 600.2^{\mathrm{a}}$ & $47,906 \pm 1249^{\mathrm{ab}}$ \\
PBP50 + CP & $35,576 \pm 1247^{\mathrm{b}}$ & $7452 \pm 600.4^{\mathrm{a}}$ & $28,124 \pm 996.4^{\mathrm{ab}}$ \\
PBP100 + CP & $38,683 \pm 1237^{\mathrm{b}}$ & $8209 \pm 407.6^{\mathrm{a}}$ & $30,474 \pm 1085^{\mathrm{ab}}$ \\
PBP200 + CP & $40,320 \pm 1898^{\mathrm{b}}$ & $9217 \pm 659.9^{\mathrm{a}}$ & $31,102 \pm 1855^{\mathrm{ab}}$ \\
\hline
\end{tabular}

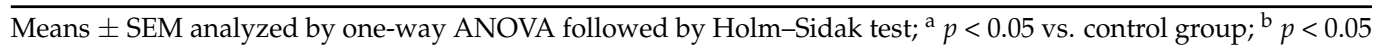
vs. CP group.

\subsection{Sperm Parameters}

The progressive motility, sperm count, and sperm viability—evaluated as parameters of sperm quality - are shown in Figure 8. The three evaluated parameters were reduced in the CP group compared with the control. PBP50 + CP, PBP100 + CP, and PBP200 + CP maintained cell viability; PBP100 + CP and PBP200 + CP preserved progressive motility; and PBP200 + CP sustained sperm count at similar levels to the control. The data suggested that PBPs at $200 \mathrm{mg} / \mathrm{kg}$ were required to recover sperm parameter alterations caused by $\mathrm{CP}$ administration in mice.
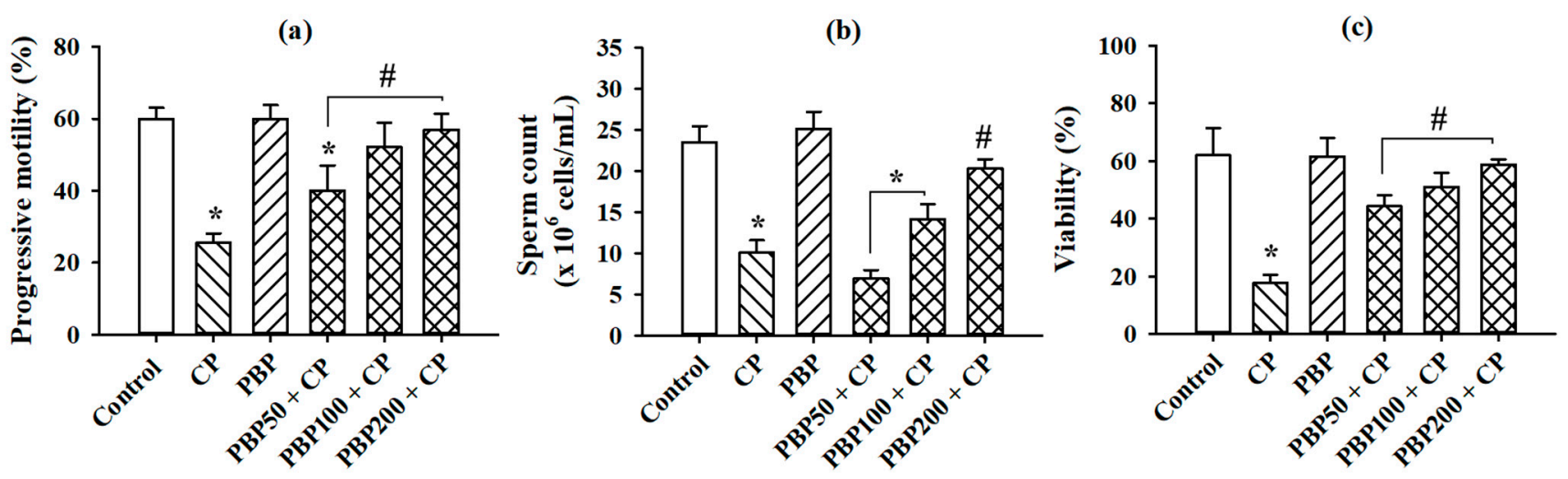

Figure 8. Effects of PBPs on sperm parameters of CP-treated mice: (a) progressive motility; (b) sperm count; (c) cell viability. Means \pm SEM analyzed by one-way ANOVA followed by Holm-Sidak test. * Indicates $p<0.05$ vs. control group; \# indicates $p<0.05$ vs. CP group.

\section{Discussion}

Although $\mathrm{CP}$ is used to treat autoimmune diseases and cancer, reproductive organ toxicity has been shown in patients and experimental models [30-32]. As CP toxicity is attributed to oxidative stress [10], and PBPs demonstrate strong antioxidant properties [33], we explored the effects of PBP crude extract on the testicular damage caused by multiple 
$\mathrm{CP}$ doses in mice. In PBP crude extract obtained from SP, we identified a higher C-PC percentage $(69.04 \%)$ than APC (30.34\%) and PE $(0.62 \%)$ (Table 1). C-PC, which is related to high antioxidant capacity [16], was reported in PBP crude extracts from SP by RodríguezSánchez et al. at a low percentage (C-CP, 47\%) [21] and by Walter et al. at a reduced concentration (C-PC, $0.237 \mathrm{mg} / \mathrm{mL}$ ) [34] as compared with our results; however, the C-PC purity index reported by Walter (0.8) correlates with our C-PC purity index result (0.7), with both index values considered to be of food grade (purity index $\geq 0.7$ ) [35]. PBP concentrations (50,100, and $200 \mathrm{mg} / \mathrm{mL}$ ) were selected according to the results observed by Castro-García et al. [22] in a rat preeclampsia model, while the duration of CP treatment was determined considering the spermatogenesis cycle [36].

Our results are in agreement with the $\mathrm{CP}$ effects previously reported by Elangovan et al. [25], Lu et al. [7], and Iqubal et al. [37] including reductions in serum testosterone, body weight, relative testis weight, and sperm parameter alterations; increases in lipoperoxidation and enzyme activity (SOD and GPX); and testicle damage observed by histology. The PBP crude extract mitigated certain CP effects, depending on the PBP dose administered. In particular, PBP at $200 \mathrm{mg} / \mathrm{kg}$ prevented changes in testosterone serum, body weight, lipoperoxidation, enzyme activity, and evaluated sperm parameters while partially ameliorating relative testicular weight loss and histological damage. Body weight loss is attributed to appetite disruption caused by sensory taste cell modifications after $\mathrm{CP}$ administration in mice [38]. Protein consumption is recommended to avoid weight loss and malnutrition in patients receiving chemotherapy [39,40]; thus, body weight recuperation observed in CP-treated mice at PBP doses of 50, 100, and $200 \mathrm{mg} / \mathrm{kg}$ was probably an effect of the protein content in the PBP crude extract.

The antioxidant effects of PBPs have been previously demonstrated [17,41], which were confirmed in our results, whereby lipoperoxidation and SOD and GPX enzymatic activity increments were prevented with PBP doses of 100 and $200 \mathrm{mg} / \mathrm{kg}$. As SOD and GPX activity, as well as lipoperoxidation [42], are proportional to oxidative stress conditions [43-45] and because the antioxidant effects of PBP are related to the capacity of C-PC to trap reactive molecules such as acrolein [46], oxidative stress-generated as a consequence of acrolein interactions-was possibly reduced by the presence of C-PC in the PBP crude extract; however, the PBP crude extract at $200 \mathrm{mg} / \mathrm{kg}$ - the highest concentration tested in our study - partially ameliorated the relative testis weight reduction and testicular damage observed by histology. Decrements in relative testicular weight were probably related to STA reductions and decreases in Leydig cells and spermatids in the CP group. Despite our histological results revealing that spermatogonia were preserved after multiple $\mathrm{CP}$ doses as previously described by Drumond et al. [47], the interstitial spaces observed in the $\mathrm{CP}$ and PBP50 + CP groups suggest Leydig cells loss. Gu et al. [48] related this to the autophagy process of Leydig cells that is induced by CP. As Leydig cells maintain testosterone secretion [49], observed testosterone reductions confirm Leydig cell loss. Although testosterone levels and interstitial spaces improved in PBP 100 and $200 \mathrm{mg} / \mathrm{kg}$ groups, suggesting that Leydig cells were recovered, STA values and relative testicular weights were lower than the control, suggesting that cell populations were deteriorated. Interestingly, the PBP $(200 \mathrm{mg} / \mathrm{kg})$-treated group without CP presented higher STA values than the control, probably because the antioxidant activity of PBPs reduced the oxidant molecules required for regular apoptosis processes [50].

On the other hand, sperm parameters such as progressive motility, sperm count, and cell viability were completely recovered at the PBP dose of $200 \mathrm{mg} / \mathrm{kg}$. The effects of the $\mathrm{PBP}$ crude extract on sperm parameter alterations in $\mathrm{CP}$-treated mice are attributable to the antioxidant activities of PBPs because damage observed in sperm is directly related to oxidative stress conditions. For example, decreased sperm motility is a result of flagellum defects caused by oxidative damage in the tubulin [51], reduced sperm count is related to spermatogenesis inhibition or apoptosis induction by oxidant molecules, and cell viability is associated with apoptosis triggered by oxidative stress [52]. 
The NADPH oxidase system (NOX)_embedded in the plasma membrane — catalyzes $\mathrm{O}^{\bullet-}$ production through the oxidation of NADPH. NADPH oxidase isoform 5 (NOX5) is a potential candidate for the ROS-generating system in spermatozoa [53,54]. NOX5 can be directly activated by PKC $\alpha$ independent of an increase in intracellular calcium [55]. Acrolein, which is likely the agent responsible for the toxicity of CP to spermatozoa, is known to activate PKC $\alpha$ [56]; hence, overactivation of NOX5 may be largely responsible for the pro-oxidative impact of $\mathrm{CP}$ on spermatozoa. Intracellular free bilirubin generated by heme oxygenase is known to inhibit various isoforms of NADPH oxidase in low nanomolar concentrations [57], although its specific effect on the NOX5 form has not been reported. Phycocyanobilin - a compound present in the chromophores of phycocyanin and allophycocyanin [17] — is converted within cells to phycocyanorubin, which is nearly identical in structure to bilirubin [58]; this may explain why phycocyanobilin has been found to mimic the NADPH oxidase-inhibitory effect of biliverdin or bilirubin in cell cultures. Our results, therefore, suggest that bilirubin and phycocyanobilin can function as inhibitors of NOX5, thereby protecting spermatozoa from acrolein. This possibility could be easily tested in vitro.

As PBP crude extract was studied in the present work, the beneficial effects observed against CP gonadotoxicity in male mice could be increased by other phytochemicals with antioxidant properties such as the polyphenols [59] and polysaccharides phycobiliproteins (PBPs) [60] previously identified in SP. Although our results suggest that PBPs ameliorate $\mathrm{CP}$ damage, this study was limited to evaluating healthy mice; hence, the effects of PBPs must be assessed in an animal model of cancer or autoimmune disease to exclude an inactivation of the therapeutic effects of $\mathrm{CP}$.

\section{Conclusions}

Phycobiliproteins crude extract at $200 \mathrm{mg} / \mathrm{kg}$ ameliorated gonadotoxicity caused by $\mathrm{CP}$ in male mice. Alterations in testosterone serum, body weight, lipoperoxidation, enzyme activity, and sperm parameters were completely prevented, while relative testicular weight loss and histological damage were attenuated; however, additional CP function tests are recommended.

Author Contributions: Conceptualization, J.B.-B., I.H.-O., M.A.M.-V. and G.C.-C.; data curation, J.B.-B.; formal analysis, J.B.-B.; funding acquisition, G.C.-C.; investigation, J.B.-B., M.A.M.-V. and R.I.M.-G.; methodology, J.B.-B.; project administration, I.H.-O. and G.C.-C.; resources, G.C.-C.; supervision, I.H.-O. and G.C.-C.; visualization, X.A.-P.; writing-original draft, J.B.-B. and X.A.-P.; writing-review and editing, X.A.-P. and G.G.-S. All authors have read and agreed to the published version of the manuscript.

Funding: This research received no external funding.

Institutional Review Board Statement: The study was conducted according to the guidelines of Mexican Official Standard NOM-062-ZOO-2001 and approved by the Bioethical Committee of the National School of Biological Sciences of the National Polytechnic Institute (protocol code: ZOO-0162020; 21 December 2020).

Acknowledgments: J.B.-B. appreciates the graduate scholarship awarded by the National Council of Science and Technology, Mexico (589497) as well as the scholarship furnished by Postgraduate Studies and Research Science, National Polytechnic Institute, Mexico (20180176). Thanks are given to Fermín Florentino Luna Coronel for helping with the testicular histology and Sihomara García Zepeda for her technical assistance.

Conflicts of Interest: The authors declare no conflict of interest.

\section{References}

1. Jalali, A.S.; Hasanzadeh, S.; Malekinejad, H. Achillea millefolium inflorescence aqueous extract ameliorates cyclophosphamideinduced toxicity in rat testis: Stereological evidences. Chin. J. Nat. Med. 2012, 10, 247-254. [CrossRef]

2. Potnuri, A.G.; Allakonda, L.; Lahkar, M. Crocin attenuates cyclophosphamide induced testicular toxicity by preserving glutathione redox system. Biomed. Pharmacother. 2018, 101, 174-180. [CrossRef] 
3. Ghobadi, E.; Moloudizargari, M.; Asghari, M.H.; Abdollahi, M. The mechanisms of cyclophosphamide-induced testicular toxicity and the protective agents. Expert Opin. Drug Metab. Toxicol. 2017, 13, 525-536. [CrossRef]

4. Wetzels, J. Cyclophosphamide-induced gonadal toxicity: A treatment dilemma in patients with lupus nephritis? Neth. J. Med. 2004, 62, 347-352.

5. Drobnis, E.Z.; Nangia, A.K. Immunosuppressants and Male Reproduction. Adv. Exp. Med. Biol. 2017, 1034, 179-210. [CrossRef]

6. Hamzeh, M.; Hosseinimehr, S.J.; Karimpour, A.; Mohammadi, H.R.; Khalatbary, A.R.; Talebpour Amiri, F. Cerium Oxide Nanoparticles Protect Cyclophosphamide-Induced Testicular Toxicity in Mice. Int. J. Prev. Med. 2019, 10, 5. [CrossRef]

7. Lu, W.P.; Mei, X.T.; Wang, Y.; Zheng, Y.P.; Xue, Y.F.; Xu, D.H. Zn(II)-curcumin protects against oxidative stress, deleterious changes in sperm parameters and histological alterations in a male mouse model of cyclophosphamide-induced reproductive damage. Environ. Toxicol. Pharmacol. 2015, 39, 515-524. [CrossRef]

8. Crisol, L.; Matorras, R.; Aspichueta, F.; Expósito, A.; Hernández, M.L.; Ruiz-Larrea, M.B.; Mendoza, R.; Ruiz-Sanz, J.I. Glutathione peroxidase activity in seminal plasma and its relationship to classical sperm parameters and in vitro fertilization-intracytoplasmic sperm injection outcome. Fertil. Steril. 2012, 97, 852-857.e1. [CrossRef]

9. Yan, L.; Liu, J.; Wu, S.; Zhang, S.; Ji, G.; Gu, A. Seminal superoxide dismutase activity and its relationship with semen quality and SOD gene polymorphism. J. Assist. Reprod. Genet. 2014, 31, 549-554. [CrossRef]

10. Liu, F.; Li, X.L.; Lin, T.; He, D.W.; Wei, G.H.; Liu, J.H.; Li, L.S. The cyclophosphamide metabolite, acrolein, induces cytoskeletal changes and oxidative stress in Sertoli cells. Mol. Biol. Rep. 2012, 39, 493-500. [CrossRef]

11. Kim, S.H.; Lee, I.C.; Lim, J.H.; Moon, C.; Bae, C.S.; Kim, S.H.; Shin, D.H.; Park, S.C.; Kim, H.C.; Kim, J.C. Protective effects of pine bark extract on developmental toxicity of cyclophosphamide in rats. Food Chem. Toxicol. 2012, 50, 109-115. [CrossRef]

12. Watcho, P.; Mpeck, I.R.; Deeh Defo, P.B.; Wankeu-Nya, M.; Ngadjui, E.; Bonsou Fozin, G.R.; Kamtchouing, P.; Kamanyi, A. Cyclophosphamide-induced reproductive toxicity: Beneficial effects of Helichrysum odoratissimum (Asteraceae) in male Wistar rats. J. Integr. Med. 2019, 17, 366-373. [CrossRef]

13. Özatik, F.Y.; Özatik, O.; Tekşen, Y.; Yiğitaslan, S.; Ari, N.S. Protective and therapeutic effect of Hydrogen sulfide on hemorrhagic cystitis and testis dysfunction induced with Cyclophosphamide. Turkish J. Med. Sci. 2021. [CrossRef] [PubMed]

14. Mulder, R.L.; Font-Gonzalez, A.; Green, D.M.; Loeffen, E.A.H.; Hudson, M.M.; Loonen, J.; Yu, R.; Ginsberg, J.P.; Mitchell, R.T.; Byrne, J.; et al. Fertility preservation for male patients with childhood, adolescent, and young adult cancer: Recommendations from the PanCareLIFE Consortium and the International Late Effects of Childhood Cancer Guideline Harmonization Group. Lancet Oncol. 2021, 22, e57-e67. [CrossRef]

15. Adewoyin, M.; Ibrahim, M.; Roszaman, R.; Isa, M.L.M.; Alewi, N.A.M.; Rafa, A.A.A.; Anuar, M.N.N. Male Infertility: The Effect of Natural Antioxidants and Phytocompounds on Seminal Oxidative Stress. Diseases 2017, 5, 9. [CrossRef] [PubMed]

16. Yu, P.; Wu, Y.; Wang, G.; Jia, T.; Zhang, Y. Purification and bioactivities of phycocyanin. Crit. Rev. Food Sci. Nutr. 2017, 57, 3840-3849. [CrossRef]

17. Pagels, F.; Guedes, A.C.; Amaro, H.M.; Kijjoa, A.; Vasconcelos, V. Phycobiliproteins from cyanobacteria: Chemistry and biotechnological applications. Biotechnol. Adv. 2019, 37, 422-443. [CrossRef] [PubMed]

18. Righini, H.; Francioso, O.; Di Foggia, M.; Quintana, A.M.; Roberti, R. Preliminary Study on the Activity of Phycobiliproteins against Botrytis cinerea. Mar. Drugs 2020, 18, 600. [CrossRef]

19. Vazquez-Sanchez, J.; Ramon-Gallegos, E.; Mojica-Villegas, A.; Madrigal-Bujaidar, E.; Perez-Pasten-Borja, R.; Chamorro-Cevallos, G. Spirulina maxima and its protein extract protect against hydroxyurea-teratogenic insult in mice. Food Chem. Toxicol. 2009, 47, 2785-2789. [CrossRef]

20. Guzman-Gomez, O.; Garcia-Rodriguez, R.V.; Quevedo-Corona, L.; Perez-Pasten-Borja, R.; Rivero-Ramirez, N.L.; Rios-Castro, E.; Perez-Gutierrez, S.; Perez-Ramos, J.; Chamorro-Cevallos, G.A. Amelioration of Ethanol-Induced Gastric Ulcers in Rats Pretreated with Phycobiliproteins of Arthrospira (Spirulina) Maxima. Nutrients 2018, 10, 763. [CrossRef]

21. Rodríguez-Sánchez, R.; Ortiz-Butrón, R.; Blas-Valdivia, V.; Hernández-García, A.; Cano-Europa, E. Phycobiliproteins or Cphycocyanin of Arthrospira (Spirulina) maxima protect against $\mathrm{HgCl}_{2}$-caused oxidative stress and renal damage. Food Chem. 2012, 135, 2359-2365. [CrossRef]

22. Castro-Garcia, S.Z.; Chamorro-Cevallos, G.; Quevedo-Corona, L.; McCarty, M.F.; Bobadilla-Lugo, R.A. Beneficial effects of phycobiliproteins from Spirulina maxima in a preeclampsia model. Life Sci. 2018, 211, 17-24. [CrossRef]

23. Maurya, S.S.; Maurya, J.N.; Pandey, V.D. Factors regulating phycobiliprotein production in cyanobacteria. Int. J. Curr. Microbiol. Appl. Sci. 2014, 3, 764-771.

24. Bennett, A.; Bogorad, L. Complementary chromatic adaptation in a filamentous blue-green alga. J. Cell Biol. 1973, 58, 419-435. [CrossRef] [PubMed]

25. Elangovan, N.; Chiou, T.J.; Tzeng, W.F.; Chu, S.T. Cyclophosphamide treatment causes impairment of sperm and its fertilizing ability in mice. Toxicology 2006, 222, 60-70. [CrossRef] [PubMed]

26. Buege, J.A.; Aust, S.D. Microsomal lipid peroxidation. In Methods in Enzymology; Fleischer, S., Packer, L., Eds.; Academic Press: Cambridge, MA, USA, 1978; Volume 52, pp. 302-310. ISBN 0076-6879.

27. Layton, C.; Bancroft, J.D.; Suvarna, S.K. 4-Fixation of tissues. In Bancroft's Theory and Practice of Histological Techniques, 8th ed.; Suvarna, S.K., Layton, C., Bancroft, J.D., Eds.; Elsevier: Amsterdam, The Netherlands, 2019; pp. 40-63. ISBN 978-0-7020-6887-4.

28. Bancroft, J.D.; Layton, C. 10-The hematoxylins and eosin. In Bancroft's Theory and Practice of Histological Techniques, 8th ed.; Suvarna, S.K., Layton, C., Bancroft, J.D., Eds.; Elsevier: Amsterdam, The Netherlands, 2019; pp. 126-138. ISBN 978-0-7020-6887-4. 
29. WHO. WHO Laboratory Manual for the Examination and Processing of Human Semen. Available online: https://apps.who.int/ iris/handle/10665/44261 (accessed on 18 September 2017).

30. Tripathi, D.N.; Jena, G.B. Astaxanthin inhibits cytotoxic and genotoxic effects of cyclophosphamide in mice germ cells. Toxicology 2008, 248, 96-103. [CrossRef] [PubMed]

31. Aguilar-Mahecha, A.; Hales, B.F.; Robaire, B. Chronic Cyclophosphamide Treatment Alters the Expression of Stress Response Genes in Rat Male Germ Cells. Biol. Reprod. 2002, 66, 1024-1032. [CrossRef]

32. Gajjar, R.; Miller, S.D.; Meyers, K.E.; Ginsberg, J.P. Fertility preservation in patients receiving cyclophosphamide therapy for renal disease. Pediatr. Nephrol. 2015, 30, 1099-1106. [CrossRef]

33. Li, W.; Su, H.-N.; Pu, Y.; Chen, J.; Liu, L.-N.; Liu, Q.; Qin, S. Phycobiliproteins: Molecular structure, production, applications, and prospects. Biotechnol. Adv. 2019, 37, 340-353. [CrossRef]

34. Walter, A.; De Carvalho, J.; Thomaz-Soccol, V.; Faria, A.; Ghiggi, V.; Soccol, C. Study of Phycocyanin Production from Spirulina platensis under Different Light Spectra. Braz. Arch. Biol. Technol. 2011, 54, 675-682. [CrossRef]

35. Chen, X.; Wu, M.; Yang, Q.; Wang, S. Preparation, characterization of food grade phycobiliproteins from Porphyra haitanensis and the application in liposome-meat system. Lwt 2017, 77, 468-474. [CrossRef]

36. Marchetti, F.; Aardema, M.; Beevers, C.; van Benthem, J.; Douglas, G.R.; Godschalk, R.; Yauk, C.L.; Young, R.; Williams, A. Simulation of mouse and rat spermatogenesis to inform genotoxicity testing using OECD test guideline 488. Mutat. Res. Toxicol. Environ. Mutagen. 2018, 832-833, 19-28. [CrossRef] [PubMed]

37. Iqubal, A.; Syed, M.A.; Najmi, A.K.; Ali, J.; Haque, S.E. Ameliorative effect of nerolidol on cyclophosphamide-induced gonadal toxicity in Swiss Albino mice: Biochemical-, histological- and immunohistochemical-based evidences. Andrologia 2020, 52 , e13535. [CrossRef]

38. Jewkes, B.C.; Gomella, M.G.; Lowry, E.T.; Benner, J.A.; Delay, E.R. Cyclophosphamide-Induced Disruptions to Appetitive Qualities and Detection Thresholds of NaCl: Comparison of Single-Dose and Dose Fractionation Effects. Chem. Senses 2018, 43, 399-410. [CrossRef]

39. Ravasco, P. Nutrition in Cancer Patients. J. Clin. Med. 2019, 8, 1211. [CrossRef]

40. Yalcin, S.; Gumus, M.; Oksuzoglu, B.; Ozdemir, F.; Evrensel, T.; Sarioglu, A.A.; Sahin, B.; Mandel, N.M.; Goker, E. Nutritional Aspect of Cancer Care in Medical Oncology Patients. Clin. Ther. 2019, 41, 2382-2396. [CrossRef]

41. Chandra, R.; Parra, R.; Iqbal, H.M.N. Phycobiliproteins: A Novel Green Tool from Marine Origin Blue-Green Algae and Red Algae. Protein Pept. Lett. 2017, 24, 118-125. [CrossRef]

42. Mladenov, M.; Gokik, M.; Hadzi-Petrushev, N.; Gjorgoski, I.; Jankulovski, N. The relationship between antioxidant enzymes and lipid peroxidation in senescent rat erythrocytes. Physiol. Res. 2015, 64, 891-896. [CrossRef]

43. Aliciguzel, Y.; Ozen, I.; Aslan, M.; Karayalcin, U. Activities of xanthine oxidoreductase and antioxidant enzymes in different tissues of diabetic rats. J. Lab. Clin. Med. 2003, 142, 172-177. [CrossRef]

44. Ceribasi, A.O.; Turk, G.; Sonmez, M.; Sakin, F.; Atessahin, A. Toxic effect of cyclophosphamide on sperm morphology, testicular histology and blood oxidant-antioxidant balance, and protective roles of lycopene and ellagic acid. Basic Clin. Pharmacol. Toxicol. 2010, 107, 730-736. [CrossRef]

45. Pavin, N.; Izaguirry, A.; Soares, M.; Spiazzi, C.; Mendez, A.; Gallas, L.; Brum, D.; Cibin, F. Tribulus terrestris Protects against Male Reproductive Damage Induced by Cyclophosphamide in Mice. Oxid. Med. Cell. Longev. 2018, 2018, 5758191. [CrossRef]

46. Zhu, Q.; Sun, Z.; Jiang, Y.; Chen, F.; Wang, M. Acrolein scavengers: Reactivity, mechanism and impact on health. Mol. Nutr. Food Res. 2011, 55, 1375-1390. [CrossRef]

47. Drumond, A.L.; Weng, C.C.; Wang, G.; Chiarini-Garcia, H.; Eras-Garcia, L.; Meistrich, M.L. Effects of multiple doses of cyclophosphamide on mouse testes: Accessing the germ cells lost, and the functional damage of stem cells. Reprod. Toxicol. 2011, 32, 395-406. [CrossRef]

48. Gu, Y.P.; Yang, X.M.; Duan, Z.H.; Shang, J.H.; Luo, P.; Xiao, W.; Zhang, D.Y.; Liu, H.Z. Squid ink polysaccharide prevents autophagy and oxidative stress affected by cyclophosphamide in Leydig cells of mice: A pilot study. Iran. J. Basic Med. Sci. 2017, 20, 1194-1199. [CrossRef]

49. Smith, L.B.; Walker, W.H. The regulation of spermatogenesis by androgens. Semin. Cell Dev. Biol. 2014, 30, 2-13. [CrossRef]

50. Liu, T.; Wang, L.; Chen, H.; Huang, Y.; Yang, P.; Ahmed, N.; Wang, T.; Liu, Y.; Chen, Q. Molecular and Cellular Mechanisms of Apoptosis during Dissociated Spermatogenesis. Front. Physiol. 2017, 8, 188. [CrossRef]

51. O'Flaherty, C.; Matsushita-Fournier, D. Reactive oxygen species and protein modifications in spermatozoa. Biol. Reprod. 2017, 97, 577-585. [CrossRef]

52. Agarwal, A.; Virk, G.; Ong, C.; du Plessis, S.S. Effect of oxidative stress on male reproduction. World J. Mens Health 2014, 32 , 1-17. [CrossRef]

53. Musset, B.; Clark, R.A.; DeCoursey, T.E.; Petheo, G.L.; Geiszt, M.; Chen, Y.; Cornell, J.E.; Eddy, C.A.; Brzyski, R.G.; El Jamali, A. NOX5 in human spermatozoa: Expression, function, and regulation. J. Biol. Chem. 2012, 287, 9376-9388. [CrossRef]

54. Villaverde, A.I.S.B.; Netherton, J.; Baker, M.A. From Past to Present: The Link between Reactive Oxygen Species in Sperm and Male Infertility. Antioxidants 2019, 8, 616. [CrossRef]

55. Chen, F.; Yu, Y.; Haigh, S.; Johnson, J.; Lucas, R.; Stepp, D.W.; Fulton, D.J.R. Regulation of NADPH oxidase 5 by protein kinase C isoforms. PLoS ONE 2014, 9, e88405. [CrossRef] 
56. Higashi, T.; Mai, Y.; Mazaki, Y. Protein kinase C-dependent cell damage by unsaturated carbonyl compounds in vascular cells. J. Biosci. Bioeng. 2018, 126, 527-532. [CrossRef]

57. DiNicolantonio, J.J.; McCarty, M.F.; O'Keefe, J.H. Antioxidant bilirubin works in multiple ways to reduce risk for obesity and its health complications. Open Heart 2018, 5, e000914. [CrossRef]

58. Zheng, J.; Inoguchi, T.; Sasaki, S.; Maeda, Y.; McCarty, M.F.; Fujii, M.; Ikeda, N.; Kobayashi, K.; Sonoda, N.; Takayanagi, R. Phycocyanin and phycocyanobilin from Spirulina platensis protect against diabetic nephropathy by inhibiting oxidative stress. Am. J. Physiol. Regul. Integr. Comp. Physiol. 2013, 304, R110-R120. [CrossRef]

59. Al-Dhabi, N.A.; Valan Arasu, M. Quantification of Phytochemicals from Commercial Spirulina Products and Their Antioxidant Activities. Evid. Based Complement. Altern. Med. 2016, 2016, 7631864. [CrossRef]

60. Chaiklahan, R.; Chirasuwan, N.; Triratana, P.; Loha, V.; Tia, S.; Bunnag, B. Polysaccharide extraction from Spirulina sp. and its antioxidant capacity. Int. J. Biol. Macromol. 2013, 58, 73-78. [CrossRef] [PubMed] 